the open beaker; in the closed system at least $53 \mu \mathrm{g}$, but possibly $91 \mu \mathrm{g}$, was converted to $\mathrm{CH}_{3} \mathrm{HgCH}_{3}$.

To study the formation of $\mathrm{CH}_{3} \mathrm{HgCH}_{3}$ from $\mathrm{Hg}^{2+}$ an entire Xiphophorus helleri (about $5 \mathrm{~g}$ ) was homogenized together with about $10 \mathrm{~g}$ of fillet from Gadus colja. The homogenate was transferred to two $50 \mathrm{ml}$. flasks. Water containing $60 \mu \mathrm{g}$ of $\mathrm{HgCl}_{2}$ was added and the volume adjusted to $25 \mathrm{ml}$. The flasks were flushed with nitrogen, made airtight with a membrane of silicone rubber and shaken for four days at $20^{\circ} \mathrm{C}$. Aliquots of the gas in the flasks were analysed as described. The gas-chromatographic analysis of the benzene gave no value for $\mathrm{CH}_{3} \mathrm{Hg}^{+}$ before treating with $\mathrm{HgBr}_{2}$ and $\mathrm{KBr}$, indicating that the mercury was originally present as $\mathrm{CH}_{3} \mathrm{HgCH}_{3}$; the mass spectrogram of the ether solution supported this. Quantitation by comparison with synthetic $\mathrm{CH}_{3} \mathrm{HgCH}_{3}$ yielded a total value of $10 \mu \mathrm{g}$ (calculated as $\mathrm{Hg}$ ) in the head-space gas.

In conclusion, the sediment from the aquarium has a higher background value for $\mathrm{CH}_{3} \mathrm{Hg}^{+}$, but also a higher biological activity than the sediment from Lake Långsjön. This may be the reason for the larger amount of $\mathrm{CH}_{3} \mathrm{Hg}^{+}$ after ten days in sediments from aquaria. The biological methylation of mereury compounds provides an explanation for the fact that $\mathrm{CH}_{3} \mathrm{Hg}_{3}+$ is found in fish, even if all known sources of mercury in the environment are in the form of inorganic mereury or phenyl mereury. The formation of the volatile $\mathrm{CH}_{3} \mathrm{HgCH}_{3}$ (b.p. $94^{\circ} \mathrm{C}$ ) may be a factor in the redistribution of mercury from aqueous industrial wastes. In Sweden emphasis has been placed. on the study of the turnover of mercury in the aquatic environment. 'The process of methylation is fundamental to a knowledge of the turnover of mercury; it may be siguificant in the uptake and distribution of mercury in fish and in the mobilization of inercury from deposits in bottom sediments into the general environment.

We thank Leif Bergstedt for help with the mass spectromotric analyses.

Institute of Analytical Chemistry,

S. JENSEN

University of Stockholm.

Swedish Water and Air Pollution

A. JERNEIöV

Rescarch Taboratory,

Stockholm.

Received March 24; rerised June 30, 1969.

${ }^{1}$ Westermark, 'T', Krichsilverfrägan i sverity. (Stockholm, 1965), 25 (1964 års Naturresursitredning, Jordbruksdepartementet, Kvicksilverkonferensen,

2 Westöö, (1., Actu Chrm. Scand., 20, 2131 (1966).

3 Jensen, S., and Jernelöv, A., Biosyntes av Metylkvicksilver I, Biocidinformation, 10, Nordforsk, May 1967.

4 Jensen, S., and Jermelov, A., Riosyntes av Metylkvicksilver II, Biocidinformation, 14, Nordforsk, Feb. 1968 .

${ }^{5}$ Hannerz, L., Annual report from Fresh Wafer Research Laboratory, Drottningholm, 1968. "Jermeliov, A., Procedings of the first hochester Conference on Woxicity,
June 1968 (in the press).

\section{Presumed Super-foetation in an Erythrocebus patas Monkey}

ON November 22 , 1964, a female specimen of Erythrocebus patas monkey was received at 'Tigoni Primate Research Centre (now the National Primate Research Centre). Her exact provenance was unknown, as she had been rescued from some peasant farmers and brought in by her rescuer. At the time of hor arrival at the contro, her second milk molars were just erupting. In 1968, after reaching adult status, she shared a cage with an adult male of the same species for several months, but mating was not actually observed.
On January 17, 1969, the male was removed from her cage. On March 8, 1969, she gave birth to a stillborn male, which was, however, "full term". Three months later on June 8,1969 , she gave birth to another stillborn baby, this time a fermale, which was also "full term".

Because the average gestation period for Erythrocebus patas is 170 days $^{1}$ this would appear to be a case of superfoetation; the first infant was sired around the ond of September 1968, and the second sometime in December.

I have not been able to trace any similar record of superfoetation in this or allied species of monkey, but our literature here is very incomplete. Super-foetation in women is, of course, a well recognized phenomenon ${ }^{2}$.

\section{S. B. LEAKEY}

National Primate Rescarch Centre,

Nairobi.

Received June 25, 1969.

1 Napier, J. R., and Napier, P. H., A Handbook of Living Primates (1969).

${ }^{2}$ Kerr, M... and Moir, C., Operative Obstetrics, 217 (1969).

\section{Evidence for Extraterrestrial Life: Identity of Sporopollenin with the Insoluble Organic Matter present in the Orgueil and Murray Meteorites and also in some Terrestrial Microfossils}

Writ very few exceptions ${ }^{1}$ the insoluble organic matter present in both Pre-Cambrian sediments and carbonacous chondrites has been neglected and organo-geochemical studies of these materials have been largely devoted to the readily solvent extractable soluble organic substances ${ }^{2}$. This is in some ways unfortunate, for by far the greater proportion of carbonaccous matter in both Pre-Cambrian sediments (up to 95 per cent) ${ }^{3}$ and in carbonaceous chondrites (up to 70 per cont) ${ }^{4}$ is insoluble and the soluble matter is frequently of a very minor nature. In addition, the soluble, and so potentially more mobile, organic
chemicals are more likely to have moved in total or in part from their point of origin, and problems of rock contamination with such substances, either over long periods through secpage or, in the case of meteorites, at impact ${ }^{5}$, are especially acute.

We have shown ${ }^{B}$ that sporopollenin which forms a major part of pollon and spore exines is an oxidative polymer of carotenoids and cerotenoid esters, and havo suggested ${ }^{7}$ that it is identical with older kerogen derived from terrestrial, especially Pre-Cambrian, sediments. We now present briefly somo results of experiments carried out on the Orgueil and Murray meteorites which in our opinion clenrly establish that the insoluble matter they contain is identical with sporopollenin.

The insoluble organic matter was isolated from samples of the Orgueil $(0 \cdot 1 \mathrm{~g})$ and Murray $(0.9 \mathrm{~g})$ meteorites as brown amorphous solids by repeated digestion with hydrofluoric and nitric acids and potassium hydroxide in the usual manner, taking maximum care in manipulation. 'The relatively large amounts of organic matter (Orgueil 3.5 per cent, Murray 4.4 per cent) would make trace contamination of little or no consequence to our subsequent chemical studics. The solids were examined by infrared spectroscopy, pyrolysis gas chromatography, potash fusion followed by thin-layer chromatography of the products and by somo elemental analyses, and rosults compared with similar cxaminations of sporopollenins
from many modern pollen and spore exines, some synthetic analogues, some microfossils and artificially metamorphosed (by heating with sand) spore exines. 